\title{
A hybrid TOPSIS-BSC method for strategic planning
}

\author{
Mohammad Reza Shojaee ${ }^{\mathrm{a}}$, Mehdi Fallah ${ }^{\mathrm{b} *}$ and Mohsen Fallah ${ }^{\mathrm{c}}$
}

${ }^{a}$ University of Shahid Beheshti, Tehran, Iran

${ }^{b}$ M.A. Student, Department of Business Administration, Ershad Damavand College, Damavand, Iran

${ }^{b}$ M.A. Student, Department of Business Administration, Babol Branch, Islamic Azad University (IAU), Iran

ARTICLEINFO ABSTRACT

Article history:

Received August 12, 2012

Accepted 28 September 2012

Available online

September 302012

Keywords:

$B S C$

TOPSIS

Strategic planning

TOPSIS-BSC

\section{Introduction}

Intangible assets such as people, patents, etc. are believed the most important components of any organizations and it could contribute to business units for continues improvement. For years, there were tremendous efforts on improving business structures through paying more attention on intangible assets. Kaplan and Norton (1992) are believed to be the first who introduced the idea of balanced scorecard (BSC) and it has been implemented for many business units, successfully (1996a; 1996b). BSC is an efficient technique to convert strategy into possible actions and monitors the consequences (Kaplan \& Norton, 2001; 2004). Since the introduction of BSC, there have been tremendous efforts on developing this technique by using multiple criteria decision making (MCDM) approaches.

\footnotetext{
* Corresponding author.

E-mail addresses: mehdyfallah@yahoo.com (M. Fallah)

\begin{abstract}
For years, tangible assets used to be the most important precious wealth of organizations. However, the recent advances in technology has changed this concept and today, intangible assets such as human resources, customers, processes are playing essential roles on making strategies. In this paper, we present a study to setup appropriate strategies using the implementation of balanced score card in four perspectives of customers, processes, learning and financial. The proposed study of this paper gathers important factors through three different brainstorming sessions and prioritize them using TOPSIS method. Based on the results of MCDM technique, selecting appropriate target market for penetration is the number one priority followed by having good accounting system and preparing for more diversified production. These are the most important items influencing strategic planning. Therefore, the study uses BSC for the first two important strategies and discusses possible actions for productivity improvement.
\end{abstract}


Sofiyabadi and Noori Nasab (2012) performed a comprehensive investigation in a dynamic BSC (DBSC) to study the strategic internal process management factors. Their proposed DBSC concentrated on internal processes perspectives, and using VIKOR and Shannon Entropy as an MCDM method, detected the internal processes, process management and improvement ranked all factors based on their relative importance.

Alvandi et al. (2012), in another work, developed a set of key performance indicators according to BSC technique for a part maker using MCDM method. They used some key performance indicators through literature reviews and experts' idea for this auto part maker, which was one of the biggest vehicle spare suppliers in Middle East. They implemented decision making trial and evaluation laboratory (DEMATEL) (Lee et al., 2011) and analytic network process (ANP) (Saaty, 1996; Saaty, 2004), respectively to measure the casual relations between the perspectives and found the relative weights for them. The results based on ANP method demonstrated that "Customer" was the most important factor. Besides, internal process, financial and learning and growth were in two to four positions.

Mozaffari et al. (2012) used MCDM technique combined with BSC to setup appropriate strategy for a nongovernmental university. They also used fuzzy variables to handle uncertainty associated with different components of BSC method. Their results indicated that outputs were more tangible for the personnel of the firm, which was explicitly accepted by the managers and officials of the university. Customer relationship management (CRM) includes several mechanisms, which endeavor to manage sustainable and profitable long-term relationships with important customers. Safari Kahreh et al. (2012) used the art of BSC for ranking developing different strategies for customer relationship management.

\section{The proposed model}

\subsection{Balanced Score Card (BSC)}

The proposed model of this paper uses BSC technique for planning appropriate strategies. The primary aim of BSC is to replace and to make the necessary changes on the traditional performance evaluation model, which is focused on financial indexes to calculate more effective evaluation of organizational performance. Note that financial aspect is yet considered as the most important perspective of organizational performance evaluation in BSC but other perspectives of traditional model also need to be considered such as customer, internal business processes and employee's growth and learning. There are four BSC perspectives as follow,

1. Financial aspect: this perspective looks on how firms take advantage of their strategic activities.

2. Customer aspect: this perspective concentrates on the some special issues that organizations take advantage of their inherent and available resources for the distinction among their competitors.

3. Internal business process aspect: all the strategic activities in a firm performed to meet stockholders and customer's expectations are studied in this perspective.

4. Growth and learning aspect: When organizations wish to keep permanent activity and development, they should always depend on constant growth and innovation.

Fig. 1 shows relationship among various aspects of BSC. 


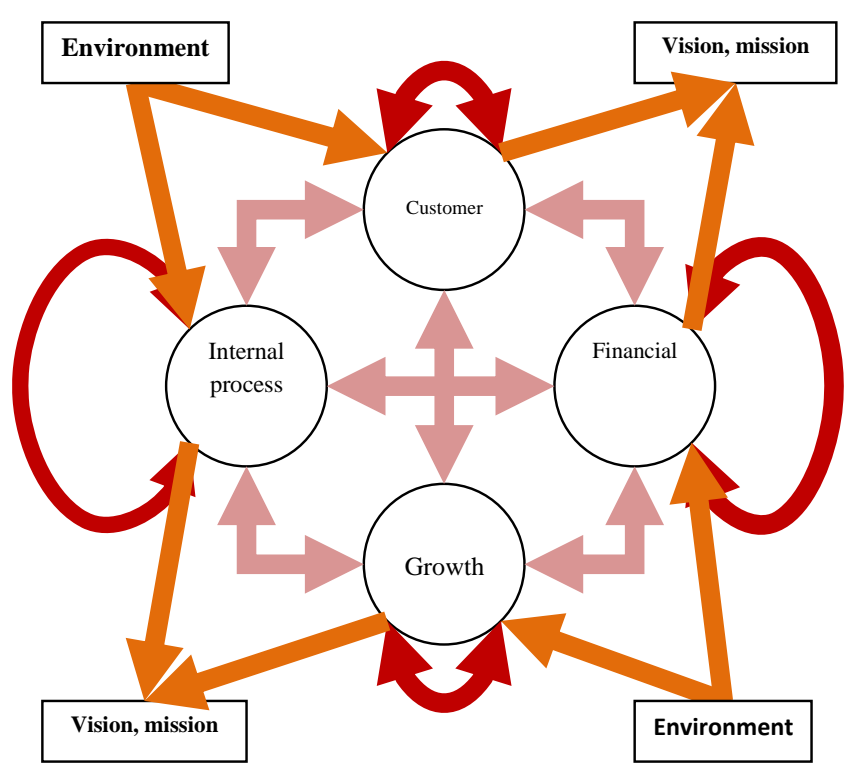

Fig.1. Relations among various aspects of BSC

\subsection{TOPSIS}

TOPSIS, originally presented by Hwang and Yoon in 1981, has been a popular ranking technique used for many real-world applications in the field of engineering (Chang et al., 2010). The standard TOPSIS method selects different alternatives, which simultaneously have the shortest distance from the positive ideal terms and the longest distance from the negative-ideal terms. The positive ideal term maximizes the highly desirable criteria while minimizes the unwanted criteria, and the negative ideal item maximizes the unwanted criteria and minimizes the desirable criteria. TOPSIS makes full use of attribute data, provides a cardinal ranking of alternatives, and does not require attribute preferences to be independent (Chen \& Hwang, 1992; Yoon \& Hwang, 1995). According to Orougi et al. (2012). Let $x_{i j}$ be the inputs for matrix of priorities where there are $i=1, \cdots, m$ alternatives and $j=1, \cdots, n$ criteria. According to Orougi et al. (2012), the implementation of TOPSIS has the following six steps,

Step 1. Construct normalized decision matrix

$$
r_{i j}=\frac{x_{i j}}{\sqrt{\sum_{i=1}^{m} \sum_{j=1}^{n} x_{i j}^{2}}}
$$

Step 2. Construct the weight normalized matrix

$v_{i j}=w_{i} r_{i j}, i=1, \cdots, m \quad j=1, \cdots, n$

Step 3. Determin the positive and negative ideal solutions

$$
\begin{aligned}
& A^{+}=\left\{v_{1}^{+}, \cdots, v_{n}^{+}\right\}, \text {where } v_{j}^{+}=\left\{\max \left(v_{i j}\right) \text { if } j \in J ; \min \left(v_{i j}\right) \text { if } j \in J^{\prime}\right\} \\
& A^{-}=\left\{v_{1}^{-}, \cdots, v_{n}^{-}\right\}, \text {where } v_{j}^{*}=\left\{\min \left(v_{i j}\right) \text { if } j \in J ; \max \left(v_{i j}\right) \text { if } j \in J^{\prime}\right\}
\end{aligned}
$$

Step 4. Calculate seperation (positive and negative) measures for each alternative

$$
S_{i}^{+}=\sqrt{\sum_{\mathrm{j}=1}^{\mathrm{n}}\left(v_{j}^{+}-v_{i j}\right)^{2}}, S_{i}^{-}=\sqrt{\sum_{\mathrm{j}=1}^{\mathrm{n}}\left(v_{j}^{-}-v_{i j}\right)^{2}}, i=1, \cdots, m
$$

Step 5. Calculate the relative closness to the ideal solution

$C_{i}^{+}=\frac{S_{i}^{-}}{S_{i}^{-}+S_{i}^{+}}, 0<C_{i}^{+}<1, i=1, \cdots, m$ 
Note that the weight of all criteria can be prioritized based on Analytical Hierarchy Process (AHP) (Saaty, 1992).

\section{Case study}

In this part of the survey, we present details of the implementation of our hybrid model for ranking seven strategies considered for a real-world case study in cabal industry. These seven strategies have been determined after having three different brain storming sessions among some experts who cordially accepted to participate in our survey. The strategies have been prioritized by implementing TOPSIS technique and Table 1 shows the results of our survey,

Table 1

The results of the implementation of TOPSIS

\begin{tabular}{llll}
\hline Strategy & Rank & Strategy & Rank \\
\hline Selecting appropriate target market to penetrate & 0.862 & Human resource development & 0.288 \\
Having good accounting system & 0.860 & Energy saving plans development & 0.244 \\
Preparing for more diversified production & 0.827 & Optimizing products packaging & 0.123 \\
Good marketing planning & 0.584 & & \\
\hline
\end{tabular}

As we can observe from the results of Table 1, selecting appropriate target market for penetration is the number one priority followed by having good accounting system. We now need to use BSC to propose appropriate strategies for strategic planning of the cable company. Table 2 demonstrates details of our actions achieved for the first priority.

Table 2

BSC perspective action plan for selecting appropriate target market for penetration

\begin{tabular}{|c|c|c|}
\hline Item & Quantitative objectives & Measures \\
\hline Financial & $\begin{array}{l}\text { Increase in sales, increase in number of } \\
\text { agent, market and demand measurement, } \\
\text { increase in brand identification }\end{array}$ & $\begin{array}{l}\text { Increase in revenue, return on investment, earning } \\
\text { before tax and interest, economic value added, } \\
\text { demand estimation, Inventory management, } \\
\text { marketing for export }\end{array}$ \\
\hline Customer & Achieving good CRM, On time delivery & $\begin{array}{l}\text { Level of services, rate of customer satisfaction, on } \\
\text { time services }\end{array}$ \\
\hline $\begin{array}{l}\text { Internal } \\
\text { processes }\end{array}$ & $\begin{array}{l}\text { Increase in quality characteristics, } \\
\text { Increase in productivity and production }\end{array}$ & $\begin{array}{l}\text { Level of quality, production life cycle, cost of } \\
\text { production }\end{array}$ \\
\hline $\begin{array}{l}\text { Learning and } \\
\text { growth }\end{array}$ & $\begin{array}{l}\text { Capability on working with automated } \\
\text { equipments and increase in skills }\end{array}$ & $\begin{array}{l}\text { Intellectual properties, skills' improvement, } \\
\text { training courses, etc. }\end{array}$ \\
\hline
\end{tabular}

We have also discussed necessary actions for having good accounting system and Table 3 shows details of our BSC implementation.

\section{Table 3}

BSC perspective action plan for having good accounting system

\begin{tabular}{|c|c|c|}
\hline Item & Quantitative objectives & Measures \\
\hline Financial & Obtaining precise cost of production & $\begin{array}{l}\text { Earnings before interest and tax, revenue, ratio of } \\
\text { overhead to revenue, average profit }\end{array}$ \\
\hline Customer & $\begin{array}{l}\text { Preparing good system for cost } \\
\text { estimation }\end{array}$ & Evaluating productivity and efficiency \\
\hline $\begin{array}{l}\text { Internal } \\
\text { processes }\end{array}$ & $\begin{array}{l}\text { Absorbing highly qualified accountants, } \\
\text { agile accounting systems }\end{array}$ & Average receivable accounts \\
\hline $\begin{array}{l}\text { Learning and } \\
\text { growth }\end{array}$ & Hiring skilled workers & $\begin{array}{l}\text { Intellectual properties, development of necessary } \\
\text { skills }\end{array}$ \\
\hline
\end{tabular}




\section{Conclusion}

In this paper, we have presented a study to determine important factors for strategic planning of a company responsible for making cable. The proposed study of this paper has gathered important factors through brainstorming and prioritized them using TOPSIS method. Based on the results of MCDM technique, selecting appropriate target market for penetration is the number one priority followed by having good accounting system and preparing for more diversified production. These are the most important items influencing strategic planning. We have also implemented BSC for the first two important strategies and discussed possible actions for productivity improvement.

\section{Acknowledgment}

The authors would like to thank the experts who cordially participated in our survey and provided some actions for productivity improvement.

\section{References}

Alvandi, M., Fazli, S., Yazdani, L., \& Aghaee, M. (2012). An Integrated MCDM Method in Ranking BSC Perspectives and key Performance Indicators (KPIs). Management Science Letters, 2, 9951004.

Chang, C. H., Lin, J. J., Lin, J. H., \& Chiang, M. C. (2010). Domestic open-end equity mutual fund performance evaluation using extended TOPSIS method with different distance approaches. Expert Systems with Applications, 37, 4642-4649.

Chen, S. J., \& Hwang, C. L. (1992). Fuzzy multiple attribute decision making: Methods and applications. Berlin: Springer-Verlag.

Kaplan, R. S., \& Norton, D. (1992). The balanced scorecard measures that drive performance. Harvard Business Review, 70(1), 71-79.

Kaplan, R.S., \& Norton, D. (1996a). Using the balanced scorecard as a strategic management system. Harvard Business Review, 74(1), 75-85.

Kaplan, R.S., \& Norton, D.P. (1996b). The Balanced Scorecard: Translating Strategy into Action. Harvard Business School Press.

Kaplan, R. S., \& Norton, D. P. (2001). The strategy-focused organization: How balanced scorecard companies thrive in new business environment. Harvard Business School Press, Boston, MA.

Kaplan, R.S., \& Norton, D.P. (2004). Strategy Maps: Converting Intangible Assets into Tangible Outcomes. Harvard Business School Press, Boston.

Lee, Y.C., Li, M.L., Yen, T.M., \& Huang, T.H. (2011). Analysis of fuzzy Decision Making Trial and Evaluation Laboratory on technology acceptance model. Expert Systems with Applications, 38(12), 14407-14416.

Mozaffari, A., Karkehabadi, H., Kheyrkhahan, M., \& Karami, M. (2012). A development in balanced scorecard by designing a fuzzy and nonlinear Algorithm (case study: Islamic Azad university of Semnan). Management Science Letters, 2, 1819-1838.

Orougi, S., Esmailzade Maghari, A., Mohammadi, H., Gol Mohammadi, A.M., \& Irani, M. (2012). An empirical investigation to use solar-geothermal hybrid energy system for small towns, Management Science Letters, 2, 2287-2292.

Saaty, T. L. (1992). How to make a decision: the analytic hierarchy process. European Journal of Operational Research, 48, 9-26.

Saaty, T. L. (1996). The analytic network process-decision making with dependence and feedback. Pittsburgh, PA: RWS Publications.

Saaty, T. L. (2004). The analytic network process: Dependence and feedback in decision making (Part 1): Theory and validation examples, SESSION 4B: Theory and development of the analytic hierarchy process/analytic network process, In The 17th International Conference on Multiple 
Criteria Decision Making, August 6-11, 2004 at The Whistler Conference Centre, Whistler, British Columbia, Canada.

Safari Kahreh, Z., Shirmohammadi, A., \& Safari Kahreh, M. (2012). An empirical study to analyze customer relationship management strategy using balanced scorecard. Management Science Letters, 2, 1603-1612.

Sofiyabadi, J., \& Noori Nasab, S. (2012). A dynamic balanced scorecard for identification internal process factor. Management Science Letters, 2, 1721-1730.

Yoon, K. P., \& Hwang, C. L. (1995). Multiple attribute decision making. Thousand Oaks, CA: Sage Publication. 